\title{
Economic Potential of Gold in Batouri (Eastern Cameroon)
}

\author{
Tchouankam Klorane Junie ${ }^{1}$, Mbog Michel Bertrand ${ }^{1}$, Bayiga ElieConstant ${ }^{2}$, Tassongwa Bernard ${ }^{1}$, NgonNgon Gilbert \\ François $^{2}$, Apouamoun Yiagnigni Roland ${ }^{1}$, Kenfack JeanVictor ${ }^{1} \&$ Etame Jacques ${ }^{2}$ \\ ${ }^{1}$ Department of earth science Faculty of sciences University of Dschang, BP: 67 Dschang Cameroon \\ ${ }^{2}$ Department of earth science Faculty of sciences University of Douala, BP: 24157 Douala Cameroon \\ Correspondence: Mbog Michel Bertrand, Department of earth science Faculty of sciences University of Dschang, BP: 67 \\ Dschang Cameroon
}

Received: December 22, 2019

Accepted: April 28, 2020

Online Published: May 6, 2020

doi:10.5539/esr.v9n2p21

URL: https://doi.org/10.5539/esr.v9n2p21

\begin{abstract}
The aim of this work is the valorization of the economic potential of gold in the Batouri region. The study is undertaken on five sites of which two alluvials (Djengo and Mongonam localities) made up of flat and river gold, two eluvials (Kambele and Bote) containing gold of veins in quarries, and one semi mechanized exploitation (METALICON) working on the two previous types. Laboratory works consist of traditional melting, determination of the various grades of gold through densimetry and spectrometry analysis and refining using the Miller Chloration method. The main results from these analyses are: i) recovery concentration is low, (about $0.5 \mathrm{~g} / \mathrm{t}$ ) for the traditional mining and higher with the semi mechanization $(1.5-2 \mathrm{~g} / \mathrm{t})$. Densimetry and spectrometry analyses show that gold of semi mechanized sites has an average grade of about 24 carats, 22 carats and 20 for alluvial and eluvial gold respectively. ii) For $26 \mathrm{~kg}$ of gold refined, a weight of $16.681 \mathrm{~kg}$ is obtained at a cost of 4051946 (four million fifty one thousand and nine hundred forty six) CFA F. Spectrometry analyses reveal the presence of silver and copper impurities, elements that can still be valorized through the presence of a gold refining unit. Hence, the absence of a gold refining unit in our country leads to poor transformation of its ores and loss of devices.
\end{abstract}

Keywords: traditional mining exploitation, traditional melting, refining, gold grade, Batouri

\section{Introduction}

The diversity of the geological formations (plutonic, volcanic, metamorphic and sedimentary) in Cameroon give it a rich subsoil full of important and interesting minerals which, if well exploited within founding projects, will inescapably lead to an emerging country by 2035 (Strategy Document for Growth and Employment ECSD, 2009). In this respects, we distinguish base metals, precious stones and precious metals notably gold.

Nowaday, the exploitation of these minerals is not mechanized, but manually done. As for the gold ores, there are two (2) types: Artisanal mining in the strict sense and semi-mechanized artisanal mining.

Mining is one of the major domains on which Cameroon directs its emergence. Indeed, the sector whose research covered up to $40 \%$ of the country (Ntep Ngwet, 2001), contributed less than $1 \%$ to the Gross Domestic Product (GDP) until August 2014 (Cadre d'Appui et de Promotion de l'Artisanat Minier, CAPAM, 2015). But now with the legal provisions of August $1^{\text {st }} 2014$, and the joint order Ministry of Finance and Ministry of Mines and Technology Development (MINFI / MINMIDT) of June $1^{\text {st }} 2015$, which empowers the CAPAM to collect the ad valorem mineral tax and corporation tax in companies engaged in less mechanized artisanal mining, there is an amelioration of economic growth (CAPAM, 2015).

Extractive metallurgy is the art of extracting metals from the earth and purifying them (Larousse, 2007). In the processing chain of gold, refining or purification process of the impurities is the last step. In Cameroon, as in countries of the sub region, there is no refining unit. The gold mined in Cameroon is refined in Dubai. Transaction costs and transport, and the by-products from refining represent a loss for the state. In addition, technical operations and treatments used in panning of gold are archaic, require much physical effort, and cause much loss. Thus it is necessary to investigate the operations and the various transformations involved in the exploitation of gold in the Batouri locality.

The objective of this work is to enhance the economic potential of gold. This involves the identification of sites of artisanal mining of gold in Batouri, the description of the existing artisanal gold-mining techniques; the treatment techniques used in determining the titres of gold in various exploitation sites, the identification of shortcomings and propose eventual solutions. 


\section{Field Descriptions and Geological Setting}

The Batouri area is located in the Eastern region of Cameroon ( $04^{\circ} 21^{\prime}$ to $04^{\circ} 29^{\prime}$ North and $14^{\circ} 17^{\prime}$ and $14^{\circ} 29^{\prime}$ East), within a humid tropical climatic zone. The geomorphology of the study area is a savanna plain with low altitudes (400$800 \mathrm{~m}$ ). It covers an area of approximately $408 \mathrm{~km}^{2}$. It comprises the localities of Djengo, Mongonam, Kambele, Bote and Metalicon (fig. 1), where samples were collected. The study area is located within the so-called «Eastern golden district » which is the most mineralized area in Cameroon. The metallogenic importance of the area is related to the geology of the whole region. It belong to the polycyclic granitic basement of Adamaoua (Toteu et al., 2004; Van Schmus et al., 2008), an intrusive syntectonic complex of N130 orientation. On the petrographic point of view, it comprises alkali granite, calc-alkali granite and charnockites; with minor quartz-syenite, syenite, quartz-diorite and gabbros. In these rocks, they are veins and lenticular bodies of quartz containing primary gold. The secondary gold (eluvial and alluvial) of Batouri is probably their alteration product and erosion.

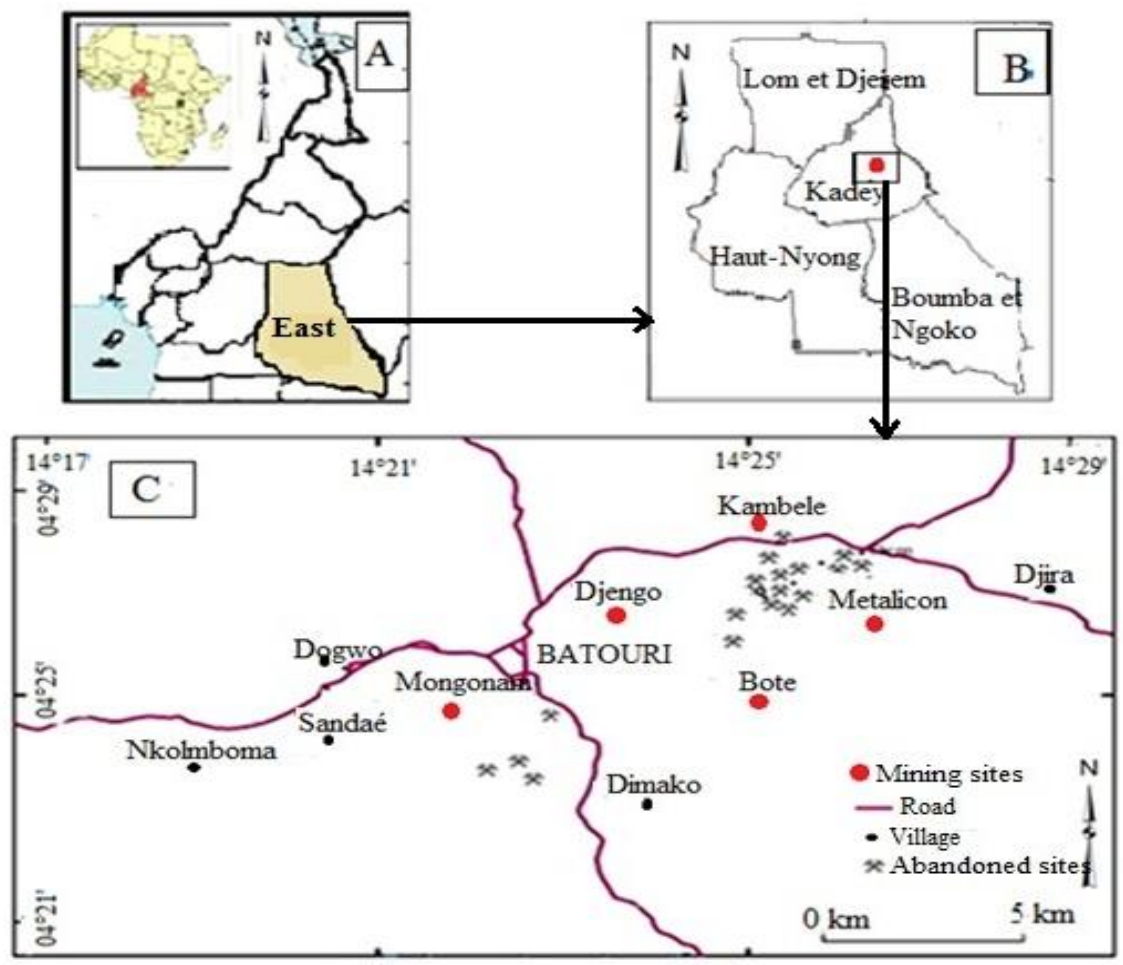

Figure 1. Map of the study area. A) Administrative map showing the East region; B) Map of the East region showing the Kadey division; C) Localisation of the study area (Asaah 2010, modify)

\section{Material and Methods}

The data collection phase was done through field campaign and laboratory works. The field campaign comprised the choice of study sites, the identification of various sites and the presentation of list of questions to stakeholders. Samples used were collected after the washing step. Laboratory work involved traditional melting of gold and the determination of different grades of gold by densimetry using by the principle of Pushed of Archimedes and X-ray fluorescence spectrometry using SKY Ray instrument, EDX pocket III model.

The concentration criterion is given by equation (1):

$$
C=\frac{6_{L}-6_{p}}{6_{l}-6_{p}}
$$

Where $\sigma_{L}$ represents the density of the heavy solid phase, $\sigma_{l}$ the density of the light solid phase, and $\sigma_{p}$ the density of the liquid used. Water is usually the liquid in which the particles are washed.

In the laboratory, artisanal gold melting and determination of different grades of gold by densimetry and $\mathrm{X}$-ray-fluorescence spectrometry were done on 22 samples.

The different losses were calculated using the following formulas: 
- Loss after acid attack denoted $\mathrm{P}_{\mathrm{a}}$ :

$$
\begin{gathered}
P_{a=P 1-P 2} \\
T_{a=\frac{P a^{* 100}}{P_{1}}} \\
\mathrm{P}_{\mathrm{f}}: P_{f=P 2-P 3} \\
T_{f=\frac{P_{f * 100}}{P_{1}}} \\
P_{T=P 1-P 3} \\
T_{G=\frac{P_{T * 100}}{P_{1}}}
\end{gathered}
$$

The determination of the gold titre by densimetry is illustrated by the following formulas:

$$
d_{A u}=\frac{\rho A u}{\rho e}=\frac{\rho A u * V e}{\rho e * V e}=\frac{m A u}{m e}
$$

$m_{A u}=\rho_{A u} \cdot V_{e}$. Where $\mathrm{V}_{\mathrm{e}}$ corresponds to the volume of water displaced, and also equal to the volume of gold bullion.

$V_{e}=V_{A u}=V_{l}$ and $m_{A u} \neq m_{l}$

$$
\begin{gathered}
d_{l}=\frac{\rho l}{\rho e}=\frac{\rho l * v e}{\rho e * v e}=\frac{m l}{m e} \\
\frac{7.1}{7.2}=\frac{d A u}{d l}=\frac{m A u}{m e} * \frac{m e}{m l}=\frac{m A u}{m l} \\
\frac{d A u}{d l} * 100=\frac{m A u}{m l} * 100=\% A u
\end{gathered}
$$

24 carats

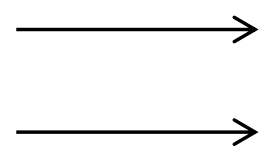

$\mathrm{X}$ carats

$\% \mathrm{Au}$

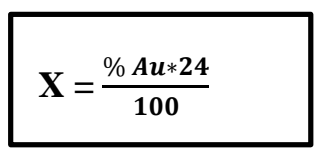

Where :

$\mathbf{X}=$ titre of gold bullion obtained

$\boldsymbol{d}_{\boldsymbol{A} \boldsymbol{u}}=$ relative density of pure gold

$\boldsymbol{m}_{\boldsymbol{A u}}=$ mass of pure gold

$\boldsymbol{m}_{\boldsymbol{l}}=$ mass of gold bullion obtained after weighing

$\boldsymbol{\rho}_{\boldsymbol{A} u}=$ density of pure gold

$\rho_{e}=$ density of water

$\mathrm{X}$-ray fluorescence spectrometry permitted the determination of the gold titre using the equation below:

$$
\text { CARAT }=\frac{\% A u * 24}{100}
$$

Where $\% \mathrm{Au}=$ Percent gold

Concerning refining, the technique involves chlorination of raw gold by the Miller process where pure gold is obtained at 99, 5\% before undergoing a second treatment, that of the Wohlwill's electrolysis where pure gold is obtained at $99.99 \%$.

\section{Results}

The use of these various methods enabled us to obtain the results presented in the following lines.

Table 1 summarizes the sites visited and the various gold grades obtained. The five sites employ about 350 craftsmen, with Djengo and Bote presenting the highest number (about 100 each). The depth of sites varies from 5 to $12 \mathrm{~m}$ and the concentration 0.24 to $2 \mathrm{~g} / \mathrm{t}$. The METALICON site is thickest and presents the highest concentration. 
Table 1. Site characteristics and corresponding gold grades

\begin{tabular}{|c|c|c|c|c|c|}
\hline \multirow{2}{*}{$\begin{array}{l}\text { Exploitation } \\
\text { sites }\end{array}$} & \multirow{2}{*}{$\begin{array}{c}\text { Type of } \\
\text { exploitation }\end{array}$} & \multicolumn{3}{|c|}{ Geographical coordinates } & \multirow{2}{*}{ COMMENTS } \\
\hline & & Latitude & Longitude & Altitude & \\
\hline DJENGO & Artisanal & N042'ㄱ'23.2” & E014²4’37.9’' & $617 \mathrm{~m}$ & $\begin{array}{l}\text { - Number of craftsmen: about } \\
100 \\
\text { - Operation "gold flats" } \\
\text {-Depth: } 5 \mathrm{~m} \\
\text { - Particle size: }<5 \mathrm{~mm} \\
\text { - Concentration: about } 0.32 \mathrm{~g} / \mathrm{t}\end{array}$ \\
\hline MONGONAM & Artisanal & N042 $26^{\prime} 44.3^{\prime \prime}$ & $\mathrm{E} 014^{\circ} 24^{\prime} 47.9^{\prime \prime}$ & $628 \mathrm{~m}$ & $\begin{array}{l}\text { - Number of craftsmen: } 50 . \\
\text { - Operation: " water gold " } \\
\text {-Particle size }<5 \mathrm{~mm} \\
\text { - Concentration: about } 0.36 \mathrm{~g} / \mathrm{t}\end{array}$ \\
\hline KAMBELE & Artisanal & N04 $28^{\prime} 42.3^{\prime \prime}$ & E014 $25^{\prime} 47.9^{\prime \prime}$ & $628 \mathrm{~m}$ & $\begin{array}{l}\text { - Number of craftsmen: } 70 \\
\text { - Operation 'gold quarry } \\
\text { "-Depth: } 10 \mathrm{~m} \\
\text {-Particle size }<5 \mathrm{~mm} \\
\text { - Concentration: about } 0.28 \mathrm{~g} / \mathrm{t}\end{array}$ \\
\hline BOTE & Artisanal & N042 $27^{\prime} 25.1^{\prime \prime}$ & $\mathrm{E} 014^{\circ} 25^{\prime} 47.2^{\prime \prime}$ & $649 \mathrm{~m}$ & $\begin{array}{l}\text { - Number of craftsmen: } 100 \\
\text { - Operation: "gold quarry" } \\
\text {-Depth: between } 8 \text { and } 12 \mathrm{~m} \\
\text {-Particle size <5mm } \\
\text { - Concentration: about } 0.24 \mathrm{~g} / \mathrm{t}\end{array}$ \\
\hline METALICON & semi mechanized & N04²6’25.1" & 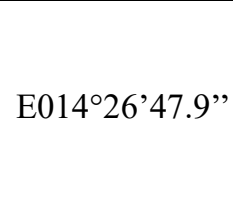 & $640 \mathrm{~m}$ & $\begin{array}{l}\text {-Cameroonian employees } 30 \\
\text { - excavation shovels: } 03 \\
\text { - Washing units } 02 \\
\text {-Depth: about } 12 \mathrm{~m} \\
\text { - Concentration: } 1.5-2 \mathrm{~g} / \mathrm{t}\end{array}$ \\
\hline
\end{tabular}

The results obtained on the different loss rates are presented in Table 2:

Table 2. Results obtained on the different loss rates

\begin{tabular}{|c|c|c|c|c|c|}
\hline $\begin{array}{c}\text { Exploitation } \\
\text { site }\end{array}$ & Gold type & $\begin{array}{c}\text { Initial weight in } \\
\text { laboratory } \mathbf{P}_{\mathbf{1}}(\mathbf{g})\end{array}$ & $\begin{array}{c}\text { Weight obtained } \\
\text { after melting } \mathbf{P}_{\mathbf{2}}(\mathbf{g})\end{array}$ & $\begin{array}{c}\text { Absolute loss } \\
\mathbf{P}_{\mathbf{3}}=\mathbf{P}_{\mathbf{1}} \mathbf{-} \mathbf{P}_{\mathbf{2}}(\mathbf{g})\end{array}$ & $\begin{array}{c}\text { Loss } \\
\text { rate }(\mathbf{\%})\end{array}$ \\
\hline DJENGO & $\begin{array}{c}\text { Alluvial } \\
\text { " water gold" }\end{array}$ & 210.56 & 195.01 & 15.55 & $\mathbf{7 . 3 8}$ \\
\hline MONGONAM & $\begin{array}{c}\text { Alluvial } \\
\text { "flat gold" }\end{array}$ & 22.94 & 19.81 & 3.13 & $\mathbf{1 3 . 6 4}$ \\
\hline BOTE & $\begin{array}{c}\text { Eluvial } \\
\text { "Quarry gold" }\end{array}$ & 500.15 & 40512 & 95,03 & $\mathbf{1 9 , 0 0}$ \\
\hline KAMBELE & $\begin{array}{c}\text { Eluvial } \\
\text { "Quarry gold" }\end{array}$ & 53.94 & 44.23 & 9.71 & $\mathbf{1 8 . 0 1}$ \\
\hline METALICON & Semi-mechanized & 218.20 & 209.47 & 8.73 & $\mathbf{4 . 0 2}$ \\
\hline
\end{tabular}




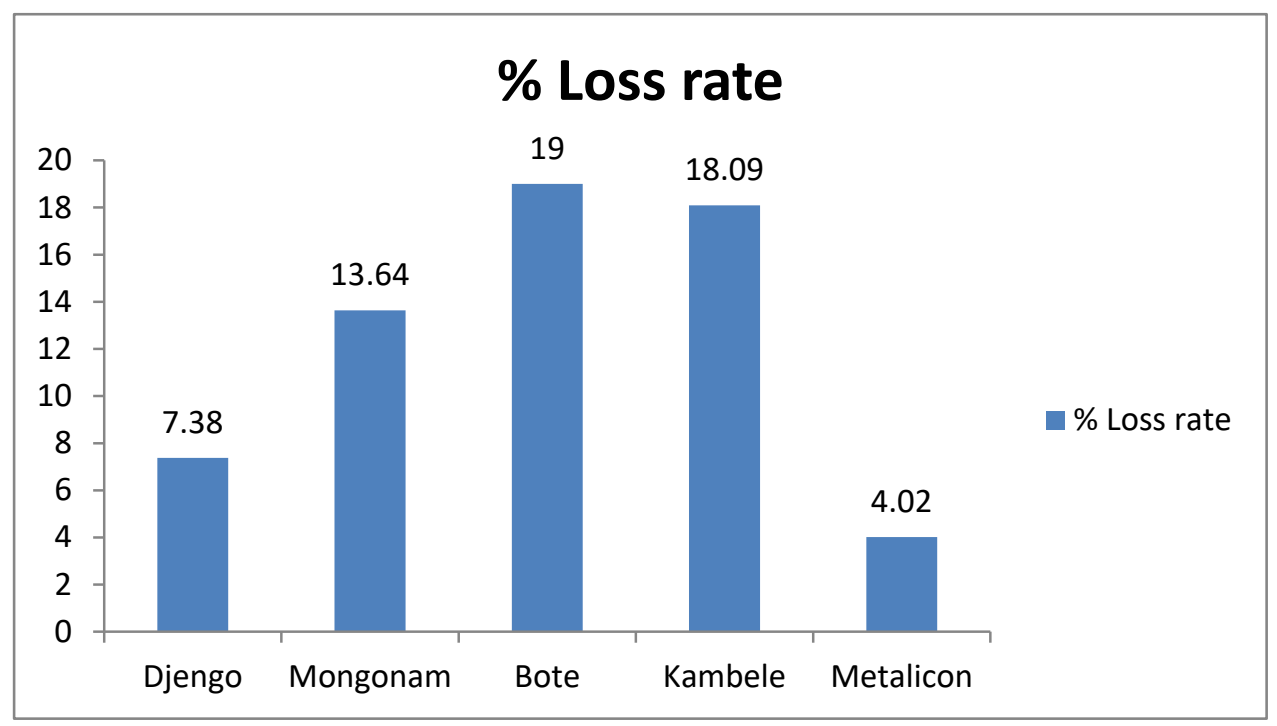

Figure 2. The different loss rates in Batouri Regoin

The eluvial gold presents the highest loss rate on melting with values amounting $19 \%$, on the contrary, alluvial gold which yields an average loss rate of $7 \%$. It should be noticed that semi mechanization reduces loss rate to $4.02 \%$ (fig. 2).

Table 3 represents the results obtained by densimetry and table 4 those through X-ray Fluorescence Spectrometry.

In Batouri alluvial gold has a mean titre of 22 carats, 20 carats for eluvial gold, both artisanal and approximately 24 carats for the semi-mechanized gold (table 3). The impurities in gold are silver and copper that can still be valorised (table 4). Gold content varies from $83.96 \%$ (KAMBELE) to $96.29 \%$ (METALICON). These sites present respectively the highest and the lowest amount of silver.

However, refining is not yet being practiced in Cameroon. Molten gold was refined in Dubai and the results are presented in the table 5.

Table 3. Gold titre of different exploitation sites

\begin{tabular}{|c|c|c|c|c|c|}
\hline Exploitation site & Gold type & Weight of boullion & $\mathbf{\%} \mathbf{A u}$ & $\boldsymbol{V}_{\boldsymbol{e}}=\boldsymbol{V}_{\mathbf{A u}}\left(\mathbf{c m}^{\mathbf{s}}\right)$ & Titre (carats) \\
\hline DJENGO & $\begin{array}{c}\text { alluvial } \\
\text { "water gold" }\end{array}$ & 195,01 & 93,21 & 9,38 & $\mathbf{2 2 , 3 7}$ \\
\hline MONGONAM & $\begin{array}{c}\text { alluvial } \\
\text { flat gold" }\end{array}$ & 19,81 & 91,71 & 0,94 & $\mathbf{2 2 , 0 1}$ \\
\hline Botuvial & "Quarry gold" & 405,12 & 85,08 & 17,83 & $\mathbf{2 0 , 4 2}$ \\
\hline KAMBELE & $\begin{array}{c}\text { Eluvial } \\
\text { "Quarry gold" }\end{array}$ & 44,23 & 83,75 & 1,92 & $\mathbf{2 0 , 1 0}$ \\
\hline METALICON & Semi-mechanized & 209,47 & 96,17 & 10,42 & $\mathbf{2 3 , 0 8}$ \\
\hline
\end{tabular}

Table 4. Gold analytical results in the various exploitation sites

\begin{tabular}{|c|c|c|c|c|c|c|c|}
\hline Exploitation site & & Weight (g) & Cu (\%) & Zn (\%) & Au (\%) & Ag (\%) & Titre (carat) \\
\hline \multirow{2}{*}{$\begin{array}{c}\text { DJENGO « alluvial } \\
\text { gold » }\end{array}$} & Test 1 & 195,01 & 0,41 & 0,00 & 93,49 & 6,10 & 22,44 \\
\cline { 2 - 7 } & Test 2 & 195,01 & 0,39 & 0,00 & 94,18 & 5,43 & 22,60 \\
\cline { 2 - 7 } & Average & 195,01 & $\mathbf{0 , 4 0}$ & $\mathbf{0 , 0 0}$ & $\mathbf{9 3 , 8 4}$ & $\mathbf{5 , 7 6}$ & $\mathbf{2 2 , 5 2}$ \\
\hline \multirow{2}{*}{$\begin{array}{c}\text { MONGONAM « alluvial } \\
\text { gold » }\end{array}$} & Test 1 & 19,81 & 0,00 & 0,00 & 92,06 & 7,94 & 22,09 \\
\cline { 2 - 7 } & Test 2 & 19,81 & 0,00 & 0,00 & 91,88 & 8,12 & 22,05 \\
\cline { 2 - 7 } & Average & 19,81 & $\mathbf{0 , 0 0}$ & $\mathbf{0 , 0 0}$ & $\mathbf{9 1 , 9 7}$ & $\mathbf{8 , 2 8}$ & $\mathbf{2 2 , 0 7}$ \\
\hline \multirow{2}{\text{BOTE}}{$\begin{array}{c}\text { eluvial } \\
\text { gold » }\end{array}$} & Test 1 & 405,12 & 4,10 & 0,00 & 85,06 & 10,84 & 20,41 \\
\cline { 2 - 7 } & Test 2 & 405,12 & 3,22 & 0,00 & 86,38 & 10,40 & 20,73 \\
\cline { 2 - 7 } & average & 405,12 & $\mathbf{3 , 6 6}$ & $\mathbf{0 , 0 0}$ & $\mathbf{8 5 , 7 2}$ & $\mathbf{1 0 , 6 2}$ & $\mathbf{2 0 , 5 7}$ \\
\hline \multirow{2}{*}{$\begin{array}{c}\text { KAMELE } \\
\text { eluvial } \\
\text { gold » }\end{array}$} & Test 1 & 44,23 & 0,00 & 0,00 & 82,98 & 17,02 & 19,92 \\
\cline { 2 - 7 } & Test 2 & 44,23 & 0,00 & 0,00 & 84,94 & 15,06 & 20,39 \\
\cline { 2 - 7 } & Average & 44,23 & $\mathbf{0 , 0 0}$ & $\mathbf{0 , 0 0}$ & $\mathbf{8 3 , 9 6}$ & $\mathbf{1 6 , 0 4}$ & $\mathbf{2 0 , 1 5}$ \\
\hline \multirow{2}{*}{$\begin{array}{c}\text { METALICON } \\
\text { «emi mecanised » }\end{array}$} & Test 1 & 209,47 & 0,00 & 0,00 & 96,22 & 3,78 & 23,09 \\
\cline { 2 - 7 } & Test 2 & 209,47 & 0,00 & 0,00 & 96,36 & 3,64 & 23,13 \\
\cline { 2 - 7 } & Average & 209,47 & $\mathbf{0 , 0 0}$ & $\mathbf{0 , 0 0}$ & $\mathbf{9 6 , 2 9}$ & $\mathbf{3 , 7 1}$ & $\mathbf{2 3 , 1 1}$ \\
\hline
\end{tabular}


Table 5. Results obtained for gold refining in Dubai (Capam, 2011)

\begin{tabular}{|c|c|c|c|c|c|}
\hline $\begin{array}{c}\text { Amount of refined } \\
\text { gold }(\mathbf{k g})\end{array}$ & $\begin{array}{c}\text { Quantity obtained after } \\
\text { refining (kg) }\end{array}$ & $\begin{array}{c}\text { Unit Cost } \\
\text { (FCFA) }\end{array}$ & $\begin{array}{c}\text { Total cost } \\
\text { (FCFA) }\end{array}$ & $\begin{array}{c}\text { Titre of gold } \\
\text { obtained in }(\boldsymbol{\%})\end{array}$ & $\begin{array}{c}\text { Total } \\
\text { Loss } \\
(\mathbf{k g})\end{array}$ \\
\hline 26,000 & 16,681 & 155844 & 4051946 & 99,5 & 9,319 \\
\hline
\end{tabular}

For $26 \mathrm{Kg}$ of gold refined in Dubai, a weight of $16.681 \mathrm{Kg}$ was obtained at a cost of 4,051,946 FCFA, averaging $10 \mathrm{~kg}$ loss that could contribute to an increase in the GDP (Gross Domestic product, table 5).

\section{Discussion}

The results from densimetric and X-ray fluorescent spectrometric methods are slightly different. This could probably be due to the fact that the densimetric method is quite complex and sometimes poses difficulties in reading the balance. The $\mathrm{X}$-ray fluorescence spectrometer has the advantage that it gives not only the chemical composition of the analyzed metal highlighting the associated elements of the gold, but also, the results are more reliable.

The values of titres for alluvial gold were higher than those of the eluvial gold. Furthermore, the lower the carat, the higher the loss rate. This is due to the fact that the eluvial gold grains often contain small boulders difficult to separate, and the presence of poorly washed ferromagnesian particles constitute impurities which in the course of melting are dissolved in nitric acid, thus increasing their loss rate.

Washing techniques used in Batouri (pan and sluice) lead to considerable loss rates of over $50 \%$.

Calculation of the concentration criterion $\mathrm{C}$ in the Batouri site

We have $\sigma \mathrm{L}=15-19.3$; Take $\sigma \mathrm{L}=16 ; \sigma \mathrm{l}=2.65$ (about 3 for some gangue minerals)

$\sigma p=1$

Finally $\mathrm{C}=7.5$

This concentration criterion was compared to Tagart's criterion table (Weiss, 1985, table 6).

Table 6. Various values of the concentration criterion C or Tagart's criterion (Weiss, 1985)

\begin{tabular}{|c|c|}
\hline Criterion & Applicability \\
\hline $\mathrm{C}>2,5$ & Easy separation \\
\hline $1,75<\mathrm{C}<1,50$ & Possible separation for the particles of dimension $>$ to $0,2 \mathrm{~mm}$ \\
\hline $1,50<\mathrm{C}<1,25$ & Possible separation for the particles of dimension $>$ to $1,65 \mathrm{~mm}$ \\
\hline $\mathrm{C}<1,25$ & Almost impossible separation \\
\hline
\end{tabular}

The criterion $\mathrm{C}$ is significantly higher than 2.5. The Batouri gold is that of easy separation (Weiss, 1985). At first the concentration methods used on different sites (sluice and panning) which are physical processes based on gravity, will give satisfactory results.

During our investigations, we found that the gold washing methods result in large losses (more than $50 \%$ ) while the actual recovery rate would be around $70 \%$.

Most of the artisanal sluices used in Batouri contain neither riffles nor strips. These traps can undoubtedly improve metal recovery yield. These processes based on proven physical laws are used on an industrial scale, an equally important aspect of the slope of the sluice. In industrial practice, the slope is on average $5^{\circ}$. In the sites visited, this angle is between 13 and $15^{\circ}$. According to International Labour Organization (ILO, 2009), for maximum gold recovery, the construction of a washing ramp provides: a manifold equipped with a grating at the bottom and a flow channel of 30 to $50 \mathrm{~cm}$ width and about one to two metres long. This channel must be fitted with a wedged under carpet webs. The sluice must be disposed at an inclined angle plane between $4^{\circ}$ and $6^{\circ}$ to claim a recovery rate of about $80 \%$.

Also, aluminum bowls or non-grooved calabash serving pan is the last stage of recovery of concentrates from Long Tom. But for a good recovery, Keita (2001) proposed to use dark grooved frames in sahelian region. He believes that the grooves can retain the gold nuggets and the colour for easy identification at night.

Hence, to reduce the strain at work and increase efficiency, this paper recommends to use the gold wash table designed and tested by the Precasem team described on figure 2: 

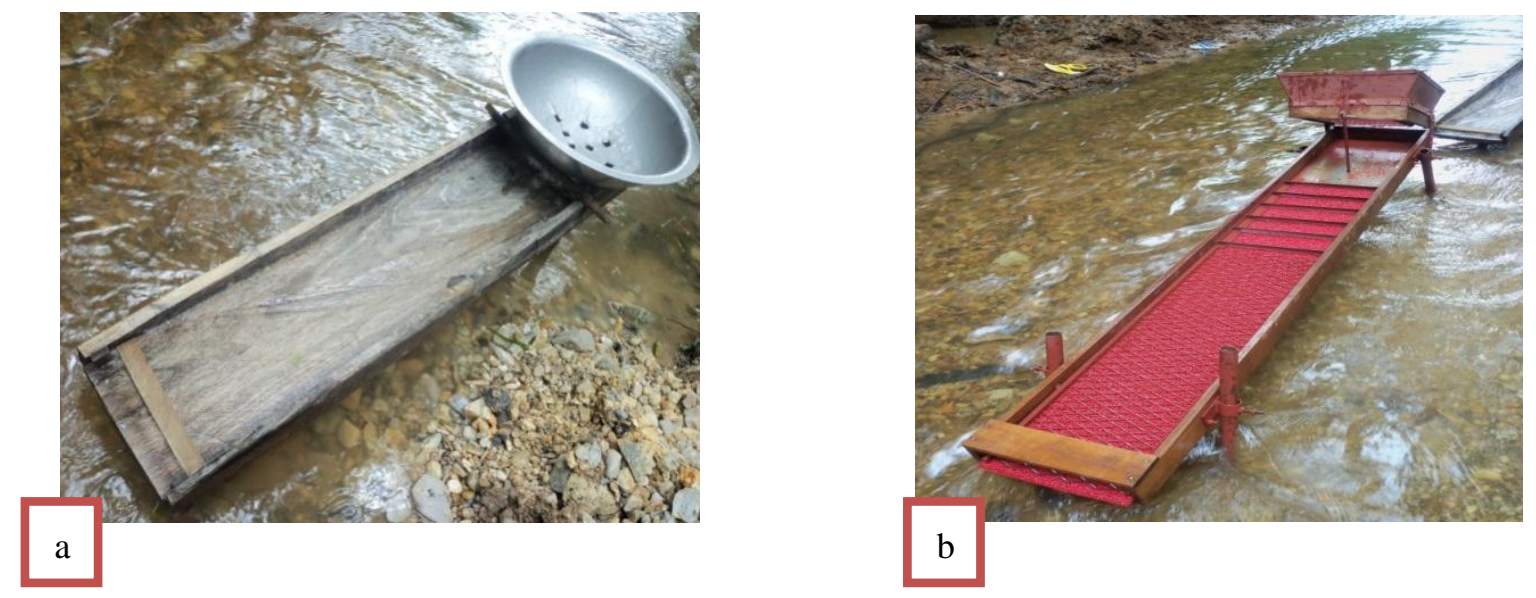

Figure 2. Gold-washing table

a) Traditional

b) enhanced

Dimensions of the pan: Length: $0.28 \mathrm{~m}$, width: $0.23 \mathrm{~m}$, height $0.12 \mathrm{~m}$. This gives us a volume of $0,00773 \mathrm{~m}^{3}$

\section{At refining}

To reduce refining costs and increase opportunities for local processing of gold, it would be better to establish a gold refining unit.

The establishment of a refining unit will enable CAPAM to put at the disposal of the Ministry of Finance 24-carat gold instead of 22 carat fused gold as is the case now. The unit will also offer products and services for clock industries, jewellery, nationally and internationally. Its activities may eventually be extended to the production of medals for decorative purposes, stamps and other alloy products with other metals (silver, copper, bronze, etc.). The production cost would be reduced due to the shortening of the production time and the increase of the quantity (table 7). Also, it will enhance the elements associated with gold. In addition, the DMCA stipulates that $15 \%$ of the production of mineral substances extracted in Cameroon must be processed locally. Refining is part of the transformation process and helps to greatly increase the value of the gold produced in Cameroon. Modifications of decree and laws on mining activities could increase the local processing rate of gold and even take it to $100 \%$, regarding refining. This will increase the utilization capacity rate of the refining unit and increase profit while ensuring better traceability of the gold produced in Cameroon.

Table 7. Test results for enhanced sluice (Precasem, 2015)

\begin{tabular}{|c|c|c|c|}
\hline $\mathbf{N}^{\circ}$ & Item & $\begin{array}{c}\text { Long Tom } \\
\text { Traditional }\end{array}$ & $\begin{array}{c}\text { SLUICE } \\
\text { (Long Tom enhanced) }\end{array}$ \\
\hline 01 & Number of washed gravel gold pans & 52 & 52 \\
\hline 02 & gravel issue washed & $0,402 \mathrm{~m}^{3}$ & $0,402 \mathrm{~m}^{3}$ \\
\hline 03 & Quantity & 1 tonne & 1 tonne \\
\hline 04 & working time & 05 hours & 01 hour \\
\hline 05 & Number of pump-motor & 02 & 01 \\
\hline 06 & Quantity of gasoline used & 04 Litres & 02 Litres \\
\hline 07 & Expenditure physical energy & Very high & Low \\
\hline $\mathbf{0 8}$ & "GOLD" PRODUCTION & $\mathbf{0 . 3 0 1}$ grams & $\mathbf{0 , 7 5 0}$ grams \\
\hline
\end{tabular}

\section{Conclusion}

The present work had as main objective the enhancement of the economic potential of gold. For this, the study was conducted in five sites, two alluvial, two eluvial, and a semi-mechanized, combined with laboratory work consisting of artisanal gold melting and determination of different titres. It follows: at the extraction, a low recovery rate for craft sites $0.5 \mathrm{~g} / \mathrm{t}$ in contrast to the semi mechanization $1.5-2 \mathrm{~g} / \mathrm{t}$. In the laboratory, the different loss rates were evaluated. Also, different titres of gold calculated by densimetric measurement and X-ray fluorescent spectrometric analysis show that semi mechanized sites have an average capacity approaching 24 carats, that of alluvial gold around 22carats and the eluvial gold around 20 . At refining, for $26 \mathrm{~kg}$ of gold which were refined, a weight of $16.681 \mathrm{~kg}$ was obtained at a cost of 4,051,946 (four million fifty one thousand nine hundred and forty-six) FCFA. However, due to the lack of a gold refining unit, the state has a shortfall in processing these ores. Also, the organization of artisans in CIG (Common Initiative Group) 
and their enlightening on modern recovery techniques will increase their production rate.

\section{Acknowledgement}

Part of this work was carried out in CAPAM and in University of Dschang in the framework of the Master thesis of Tchouankam Klorane Junie.

\section{References}

Akwinga, A. V. (2010). Lode gold mineralisation in the Neoproterozoic granitoids of Batouri, southeastern Cameroon. Univ.-Bibliothek.

Awono A. J. (2012). Sustainable management of mining exploitation in Cameroon: Case of the little gold mine of Bétaré Oya (East Cameroon). Master thesis specialized in sustainable mining management, 2IE Foundation Burkina Faso, p60.

Aybeka, K. (2010). Artisanal exploitation of gold and development in the Mambasa and Wamba territories (Eastern Province, DR Congo), online dissertation, Catholic University of Graben.

Bagnouls, \& Gaussen, H. (1957). Biological climate and its significance. Ann. Geol., XXVI, 193-220. https://doi.org/10.3406/geo.1957.18273

Blazy, P. (2005). Engineering techniques, gold metallurgy (1st ed.). October 1956, p220.

CAPAM. (2015). Memorandum of gold canalisation prices.

ECSD. (2009). Framework of government action for the period 2010-2020, 168P.

HIPC Project / MINMIDT / CAPAM (2007). Training mining CIGs in mineral exploration, exploitation and processing of minerals, p30.

Keita, S. (2001). Study on Artisanal mining and surface mining on a small scale in Mali, p126.

Larousse. (2007). French dictionary. Paris, France, p266.

Le Roux, X., \& Bariac, T. (1998). Seasonal variations in soil, grass and shrub water status in a West African humid savanna. Oecologia, 113(4), 456-466. https://doi.org/10.1007/s004420050398

Mengue, F. D. (2012). Well water quality and drilling in the Ketté sector, DIPES II dissertation in Biological Sciences. Higher Teachers Training College Yaounde 10p.

Nédélec, A., Nsifa, E. N., \& Martin, H. (1990). Major and trace element geochemistry of the Archaean Ntem plutonic complex (South Cameroon): petrogenesis and crustal evolution. Precambrian Research, 47(1-2), 35-50. https://doi.org/10.1016/0301-9268(90)90029-P

Ntep Ngwet, P. (2011). Support to development of mining activities (CAPAM). Program 2011-2016, p320.

Ntep, G. P., Dupuy, J. J., Matip, O., Fombutu, A., Fogakoh, E., \& Kamgui. (2001). Cameroon Mineral resources; Explanatory note of the thematic map of Cameroon's mineral resources on a geological background, p375.

Ntep, N. P., \& Adeline, T. (2005). Environmental Research of Lom Pangar dam. Theme 11: Mining, 24-26.

OIT. (2009). Security and optimization techniques of exploitation and processing of gold washing sites of Komabangou and M'Banga, p11-13.

Radec. (2009). Socio-economic study for the development of the management plan of the communal forest of Batouri, report, p67.

Rafolo, A. N. (2008). Improvement study of a home-made unit of gold bars. End of study dissertation at the Polytechnic School of Antananarivo (ESPA), p7-9.

Regnoult, J. M. (1986). Geological synthesis of Cameroon, Ministry of Mines and Energy. Yaounde, Cameroon, p119.

Toteu, S. F., Van Schmus, W. R., Penaye, J., \& Nyobe, J. B. (1994). U Pb and Sm N edvidence for Eburnian and Pan-African high-grade metamorphism in cratonic rocks of southern Cameroon. Precambrian Research, 67(3-4), 321-347. https://doi.org/10.1016/0301-9268(94)90014-0

Tsaléfac, M. (2007). Climate in Atlas of Cameroon. In N. Houstin, \& C. Seignobos. Les eds. Editions Jeune Afrique, Paris), p62-63.

Van Schmus, W. R., Oliveira, E. P., Da Silva Filho, A. F., Toteu, S. F., Penaye, J., \& Guimarães, I. P. (2008). Proterozoic links between the Borborema province, NE Brazil, and the central African fold belt. Geological Society, London, Special Publications, 294(1), 69-99. https://doi.org/10.1144/SP294.5 


\section{Laws, decrees and orders related to this work}

Order No. 064 / PM of 25 July 2003 Relative to the creation, organization and functioning of Small Scale Mining Support and Promotion Framework Unit (CAPAM).

Law No. 001 of 16 April 2001, bearing mining code.

Decree No. 2002/648 / PM of 26 March 2002 laying down the procedures for implementing. Law No. 001 of April 16 on the Mining Code.

Law $\mathrm{N}^{\circ} 2010 / 011$ of 29 July 2010 amending and supplementing that of No. 001 of 16 April 2001 relating to the Mining Code.

Decree No. 2014/1882 / PM of 4 July 2014 amending and supplementing that of N$^{\circ}$ 2002/648 / PM of 26 March 2002 laying down the procedures for implementing Law No. 001 of April 16 on the Mining Code.

\section{Copyrights}

Copyright for this article is retained by the author(s), with first publication rights granted to the journal.

This is an open-access article distributed under the terms and conditions of the Creative Commons Attribution license (http://creativecommons.org/licenses/by/4.0/). 